\title{
LEGER VANDRER INN
}

Åutdanne en lege i Norge koster ca. 2,3 millioner kroner. Noen mener staten sparer penger når ferdigutdannede, utenlandske leger kommer til Norge. Mange kommer fra land med legeunderskudd. Er det uproblematisk?

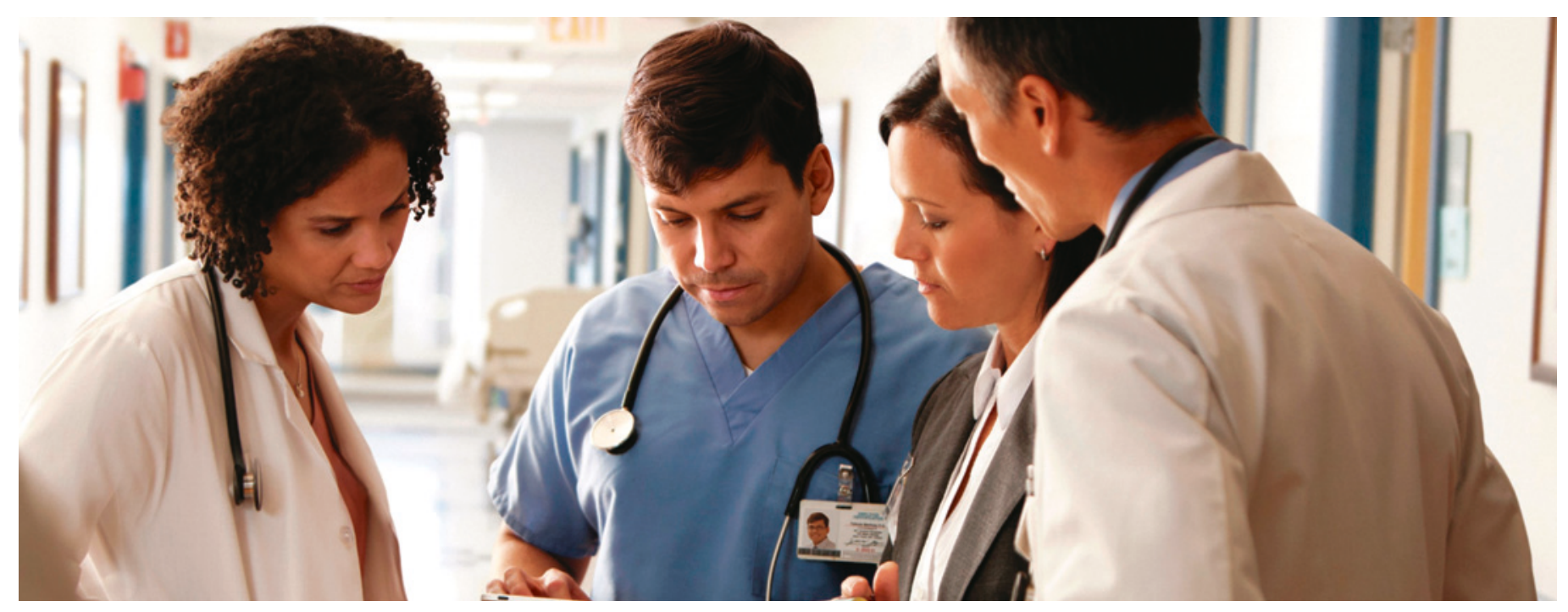

Illustrasjonsfoto: NTB scanpix

Statistikk fra Legeforeningen viser at i dag er rundt én av seks leger i Norge utenlandske statsborgere. For overleger er andelen enda høyere - her er mer enn én av fem fra utlandet.

- På ti år har antallet utenlandske leger som bor og jobber i Norge, økt med $40 \%$. Av landets 23500 yrkesaktive leger under 67 år er 16,5\% utenlandske statsborgere. Av landets 7085 overleger er 20,5\% utlendinger, sier statistikksjef Anders Taraldset i Legeforeningen til Tidsskriftet.

\section{Flest tyskere}

Etter EU-utvidelsene østover i 2004 og 2007 har antallet østeuropeiske leger som kommer til Norge, økt kraftig. Det er også en stor økning i østeuropeiske leger fra andre land utenfor EU, som blant annet Serbia, Russland og Ukraina. Det er likevel flest tyske, danske og svenske leger som kommer til Norge.

\section{Uetisk?}

Tall fra Kunnskapsdepartementet viser at det koster i underkant av 2,3 millioner kroner å utdanne en lege i Norge. Leder i Norsk medisinstudentforening, Even Holth Rustad, mener det er bekymringsverdig at vi blir avhengig av legeimport og at vi sender regningen for velferdsstaten til land som er fattigere enn oss.

- Det er billig og passer bra å hente ferdig utdannede spesialister fra utlandet, men det umoralsk å gjøre dette når legene trengs i hjemlandet og Norge har penger tilå utdanne egne leger, sier Rustad til Tidsskriftet.

\section{Hjerneflukt?}

Noen mener at Norge bidrar til hjerneflukt og legemangel i fattigere land. Er legeinnvandringen problematisk for Norge og for landene legene kommer fra?

- Legeinnvandringen er i seg selv ikke problematisk for Norge hvis legene som kommer fyller alle krav de må og det er jobber nok. Det litt pussige er vel heller at det virker som vi er avhengige av legeinnvandringen. På noen litt mindre sykehus utgjør andelen leger med oppvekst og utdanning i utlandet ca. to tredeler av overlegene, sier Jon Helle, leder av Overlegeforeningen til Tidsskriftet.

Han mener det etiske dilemmaet avhenger av om disse legene kommer fra land som har overskudd eller underskudd av leger.

- Noen land har ekstremt legeunderskudd, og da er det slett ikke uproblematisk. Som rikt land burde vi vel heller hatt en viss mulighet for netto eksport av leger, hvilket virker helt hypotetisk, sier Helle.

Statssekretær Anne Grethe Erlandsen i Helse- og omsorgsdepartementet har ikke vært tilgjengelig for kommentar, men sier til Stavanger Aftenblad at legeinnvandringen er uproblematisk og bare er en konsekvens av et felles arbeidsmarked.
«Det er bekymringsverdig at vi blir avhengig av legeimport»

Even Holth Rustad

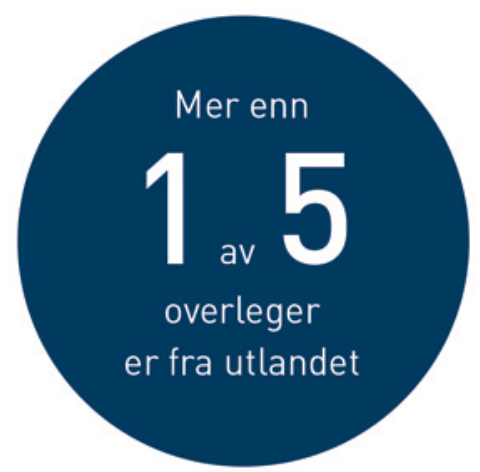

